\title{
MACRO- AND MICROMORPHOLOGY OF THE ROOT, STEM, LEAF, INFLORESCENCE AND FRUIT OF EUPHORBIA PEPLUS L. GROWING IN EGYPT
}

\author{
A. A. Ali, H. M. Sayed, S. R. Mohamed and A. M. Zaher* \\ Department of Pharmacognosy, Faculty of Pharmacy, Assiut University, Assiut, Egypt
}

\begin{abstract}
Euphorbia peplus L. belongs to Family Euphorbiaceae which includes about 283 genera with almost 7500 species. They are distributed all over the world mainly tropical countries. Some species of the genus Euphorbia showed antiviral and anticancer activities. It was reported to be used in folkloric medicine as purgative and in treatment of skin diseases, gonorrhea, liver disorders, chest diseases, and gout. Some phytochemical studies have been carried out abroad on different species. The authors carried out phytochemical and biological studies on the studied plant and here in we undertake macro- and micromorphological studies with the aim of finding out the diagnostic features by which the plant could be identified in both entire and powdered forms.
\end{abstract}

\section{INTRODUCTION}

Euphorbiaceae (spurge family) is one of the largest families of higher plants comprising about 283 genera and 7,500 species ${ }^{1-8}$ represented by herbs, shrubs, trees sometimes succulent and cactus-like and characterized by the frequent occurrence of white sap. Members of the family occur mainly in the warmer climates. The genus Euphorbia is the largest one in the family Euphorbiaceae, comprising about 1600 species $^{2}$, represented by herbs, shrubs or small trees of various habits. The juice of many Euphorbia species is acrid poisonous, especially if it comes in contact with mucous membranes of open sores while the latex from some species is used medicinally as purgative, fish poison and as insecticide? Some species are grown domestically as ornamental $^{2}$. Different Euphorbia species showed antiviral and anticancer activities ${ }^{10}$, while others used for treatment of skin diseases, gonorrhea, liver disorders, chest diseases, and gout ${ }^{5}$. Euphorbia peplus L. has been used medicinally for treatment of asthma, catarrh and as purgative ${ }^{11}$.

Received in 26/12/2011 \& Accepted in 9/10/2012
Preliminary phytochemical screening of Euphorbia peplus L. revealed the presence of sterols, triterpenes, flavonoids and tannins. Some chemical studies have been carried out on this plant concerning its constituents where diterpenes, triterpenes and flavonoids have been identified from it ${ }^{12-20}$.

Phytochemical study of the plant growing in Egypt revealed the isolation of sixteen compounds: $\alpha$-amyrin, hexacosanol, $\beta$ sitosterol, stigmasterol, oleanolic acid, $\beta$ sitosterol 3-O-glucopyranoside, $\beta$-sitosterol 3$O$-glucouronide, $P$-hydroxy benzoic acid, quercetin, kaempferol, methyl gallate, quercetin-3-O-glucoside, kaempferol-3- $O$ glucoside, kaempferol-3-O-rhamnoside, kaempferol-3-O-rutinoside and rutin $^{21}$. The biological study of the different plant extracts showed: anti-inflammatory, analgesic, antipyretic and cytotoxic activities ${ }^{21}$. However nothing could be traced concerning its macroand micromorphological characters. This encouraged us to undertake a macro- and micromorphological characters of the different organs of Euphorbia peplus L. with the aim of finding out the diagnostic features by which the plant could be identified. 


\section{Habitat}

Euphorbia peplus L. (Figs. 1\&2) is an annual erect, cylindrical, glabrous, light green weed. It reaches about $25 \mathrm{~cm}$ in height with numerous branches, the branches freely occur from the base. It carries simple alternate or opposite, exstipulate, shortly petiolate ovate to broadly ovate leaves. The Inflorescence (cyathium) (Fig. 2) is floral like, monoeious, yellowish green in color. Flower bud appears in March and opens in April. The fruits (Fig. 2) are globular capsules, enclosing three seeds. They mature at the end of May. The weed grows in muddy solitary soil.

\section{Material}

The plant material used in this work was the whole plant of Euphorbia peplus L. The plant was collected during the flowering stage in April from Assuit University Campus and was kindly identified by Prof. Dr. Abd Elaziz Fayed Prof. of Plant Taxonomy, Botany Department, Faculty of Science, Assiut University. Different organs samples were preserved in mixture of alcohol (70\%): glycerol: water $(1: 1: 1)$ and stored in tightly closed container. Other samples were separately air dried and reduced to fine powder.

\section{THE ROOT}

A) Macromorphology of the root (Figs. 1\&2)

The root is cylindrical in shape fusiform tap root, measuring about $(3-\underline{5}-6) \mathrm{cm}$ in length and nearly $0.5 \mathrm{~cm}$ in diameter at the top. It bears numerous tapering lateral rootlets. Externally it is reddish brown to brown in color and longitudinally wrinkled. The fracture is hard. It has a faint odor and slight burning taste.

\section{B) Micromorphology (Fig. 3)}

A transverse section in the root (Fig. 3) is nearly circular in outline. It shows an irregular narrow brownish cork surrounding a narrow parenchymatous phelloderm containing simple and rounded starch granules. The vascular bundle is composed of a narrow phloem and wide xylem separated by few rows of cambial cells and traversed longitudinally by uni- and biseriate medullary rays.

The cork is formed of a narrow zone of 3-4 rows of brownish, somewhat tangentially elongated cells (Fig. 3). In surface view (Fig. 4) they are polygonal with thick superized and straight anticlinal walls, measuring about (1533-37) $\mu$ in length, (17-20-22) $\mu$ in width and (5-7-10) $\mu$ height.

The phelloderm is formed of several oval to elongated parenchymatous cells with thin cellulosic walls (Fig. 3) containing numerous simple starch granules which are rounded in shape and measuring about (2-2.5-3) $\mu$ in diameter. Laticiferous tubes ${ }^{8 \& 9}$ are scattered in the cortical tissue and measuring about (230300-345) $\mu$ in length and (10-13-15) $\mu$ in diameter. They are stained dark brown with iodine (T.S).

The vascular system is formed of a continuous ring of phloem and xylem, separated by a narrow cambium and traversed longitudinally by medullary rays.

The phloem consists of a narrow zone of thin walled cellulose elements including; sieve tubes, campanion cells and phloem parenchyma (Fig. 3). Several scattered yellowish brown laticiferous tubes are present and measuring about (10-13-17) $\mu$ in diameter. The phloem is traversed by parenchymatous medullary ray cells which are uni or biserriate. The medullary ray cells are mostly subrectangular in shape.

The cambium is formed of 2-3 layers of thin walled subrectangular to tangentially elongated meristematic cells (Fig. 3).

The xylem is a comparatively wide cylinder of lignified elements. The vessels showing lignified spiral, reticulated and pitted thickening and measure about (15-27-35) $\mu$ in diameter. The wood parenchyma consists of sub rectangular to polygonal cells with slightly lignified walls, with simple pits. They measure (30-38-40) $\mu$ in length and have (14-16-23) $\mu$ in width. The wood fibers are elongated, lignified with simple pits, acute apices, wide lumena and measuring about (400-476-490) $\mu$ in length and (16-18-19) $\mu$ in width. The trachieds have thick lignified walls, showing numerous pordered pits, they measure about $(45-100-120) \mu$ in length and about (19-26-30) $\mu$ in width as well as trachiedal vessels that measure about (300332-354) $\mu$ in length and (20-33-53) $\mu$ in width. 


\section{C) Powdered root (Fig. 4)}

The powdered root is yellowish-brown in color. It has slightly burning taste and faint odor. It is characterized microscopically by the presence of the following diagnostic fragments:

1- Fragments of brownish cork consist of polygonal thin-walled non lignified cells.

2- Fragments of lignified xylem vessels with spiral, reticulate and pitted thickning, in addition to lignified wood parenchyma, medullary ray cells, trachieds and trachiedal vessels.

3- Fragments of wood fibres with wide lumina, blunt apices and thick lignified walls.

4- Fragments of cortical parenchymatous cells containing simple starch granules.

5- Fragments of non branched laticeferous tubes containing latex which stains brown with iodine (T.S).

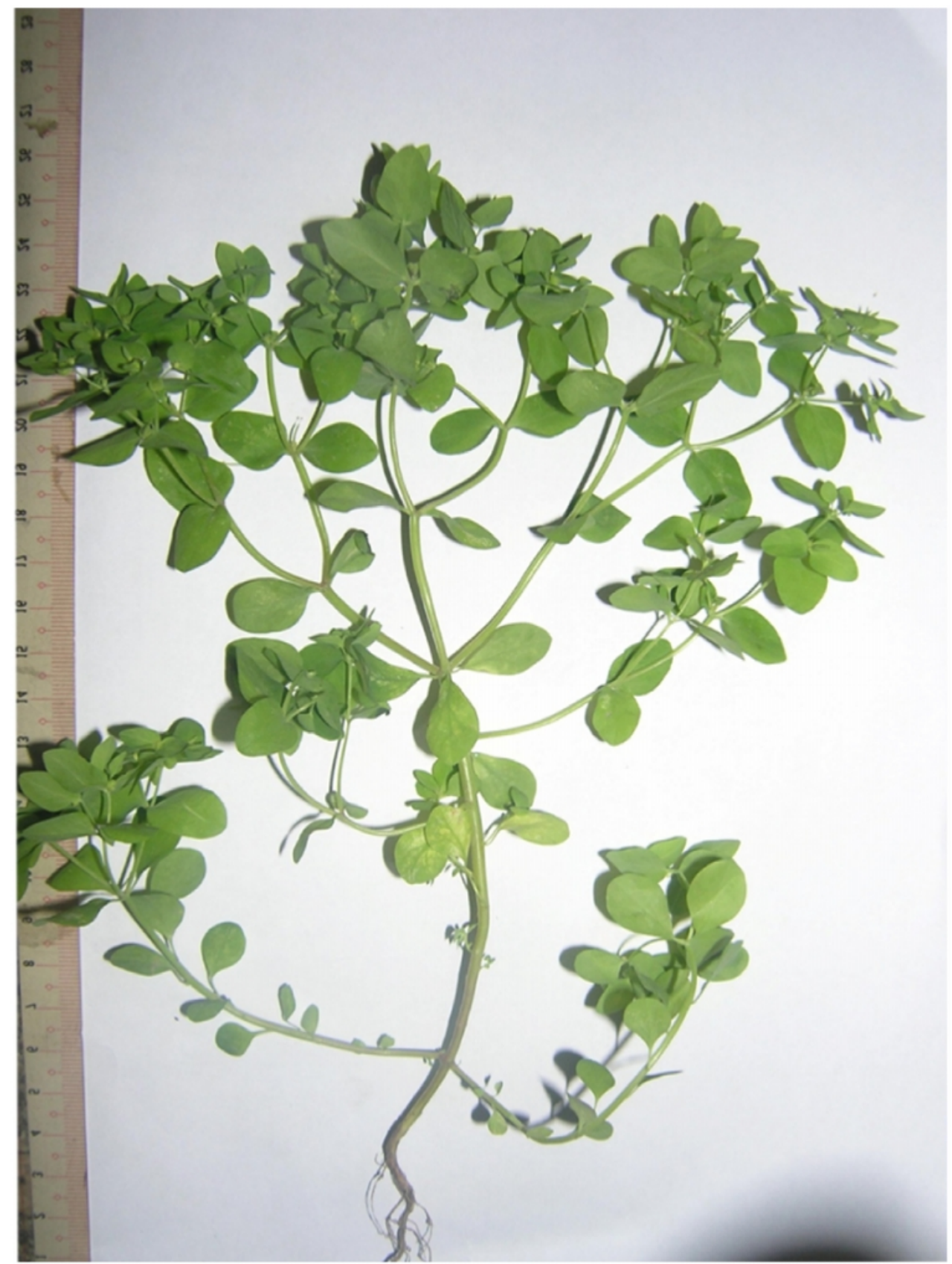

Fig. 1: Photo of the plant

x 0.68 


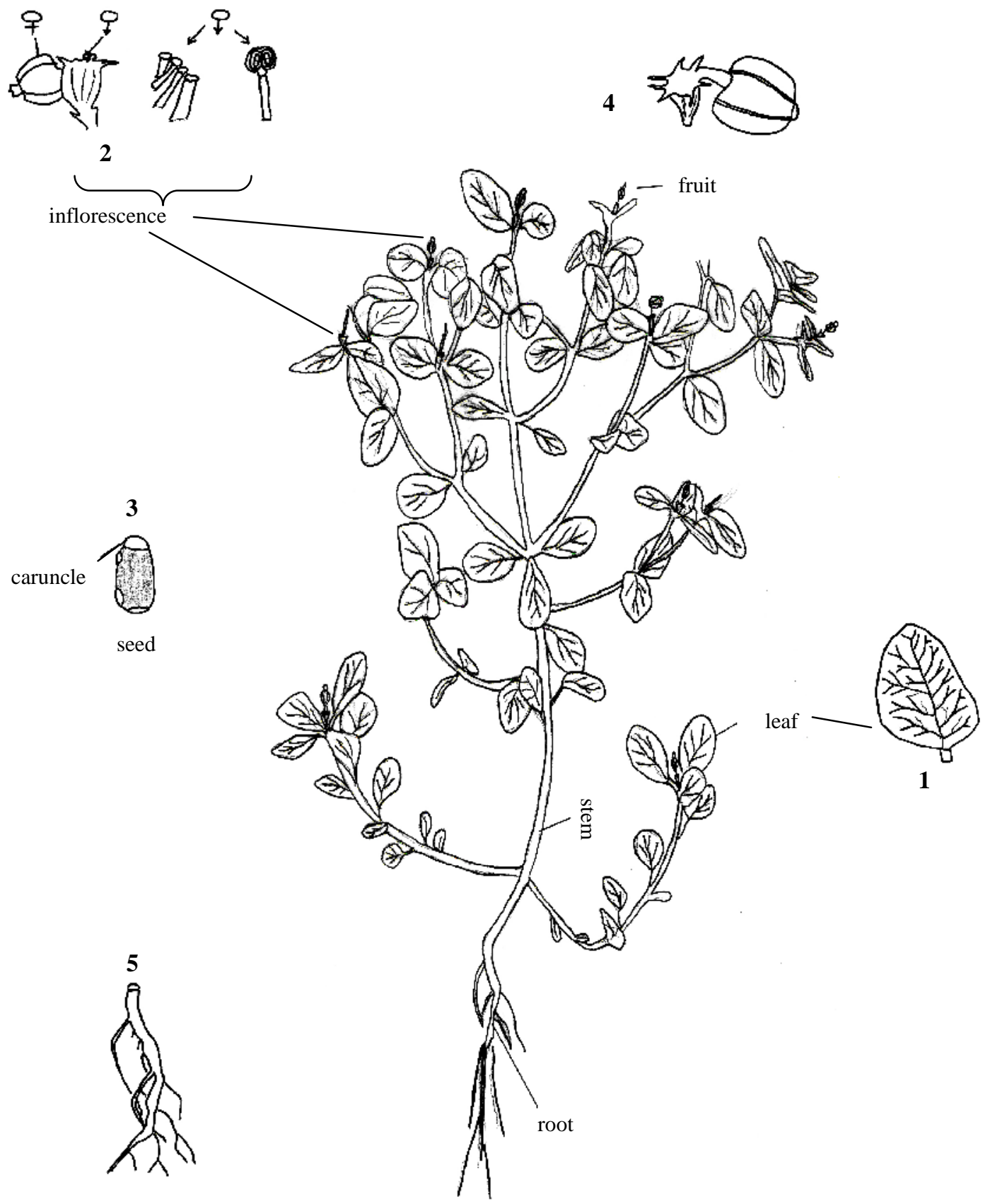

Fig. 2: Macromorphology of Euphorbia Peplus L.

1- The leaf

2- The inflorescence

3- The seed

4- The fruit

5- The root $\mathrm{x} 1.0$ 


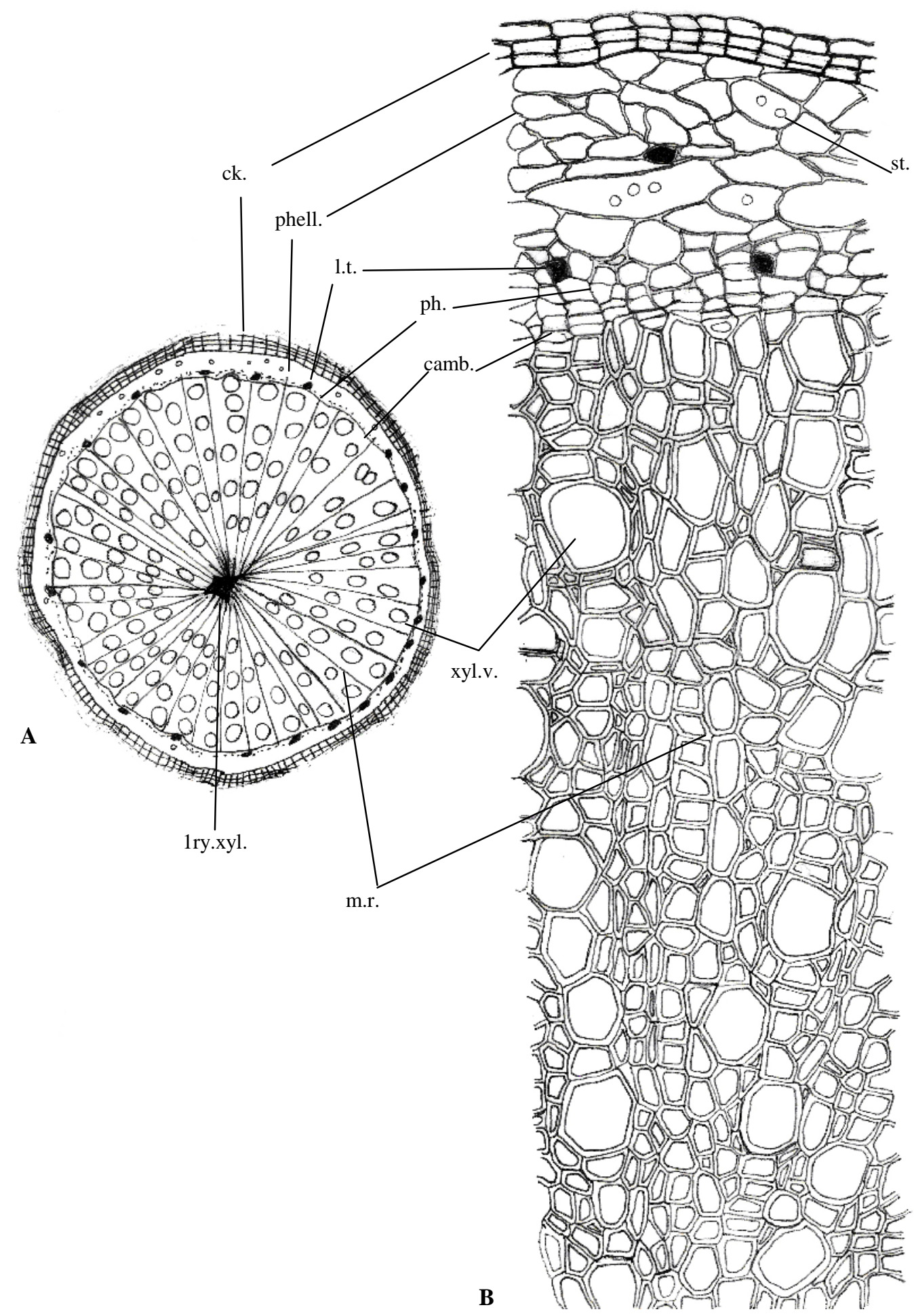

Fig. 3: T.S. of the root.

A: Diagrammatic T.S. of the root $\quad x 150$

B: Detailed T.S. of the root $\quad$ x 300

camb.: cambium, ck.: cork, 1.t.: latex tube, m.r.: medullary ray, phell.: phelloderm, ph.: phloem, 1ry.xyl.: primary xylem, st.: starch, xyl.v.: xylem vessel. 

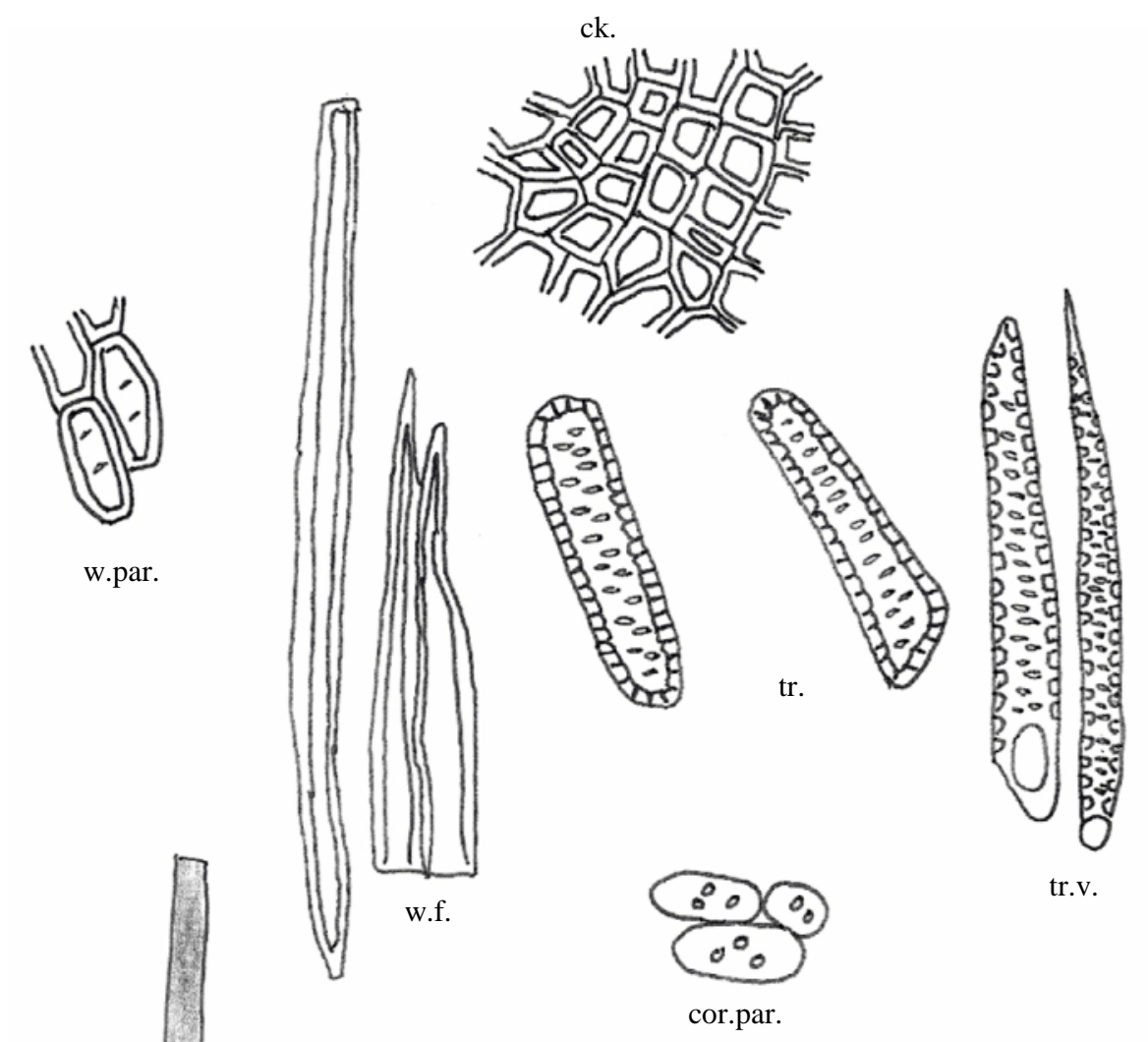

Fig. 4: Powdered elements of the root

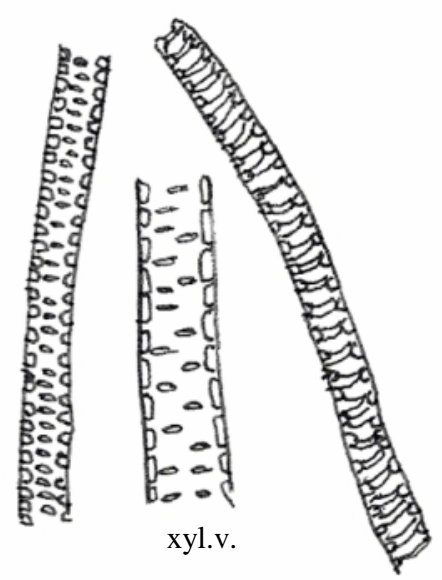

x 200

ck.: cork cells, cor.par.: cortical parenchyma, 1.t.: latex tube, m.r.: meullary rays, tr.: trachides, tr.v.: trachiedal vessels, w.f.: wood fibre, w.par.: wood parenchyma, xyl.v.: xylum vessels.

\section{THE STEM}

\section{A) Macromorphology of the stem (Figs.} $1 \& 2)$

The stem is erect, cylindrical, sympodially branched reaching about $(7-\underline{10}-25) \mathrm{cm}$ in height and $(0.2-0.3-0.5) \mathrm{cm}$ in diameter. It carries numerous alternate to opposite branches with short internodes measuring about $0.8-2 \mathrm{~cm}$ in length. The stem is light green in color at the upper parts, while the lower parts are reddish in color. The stem is glabrous with faint odor and burning irritant taste.

\section{B) Micromorphology of the stem (Fig. 5)}

A transverse section in the stem is nearly circular in outline. It consists of an outer epidermis, comparatively narrow cortex 
consisting of few rows of collenchyma followed by parenchyma cells containing starch granules, the endodermis is indistinct. The pericycle is formed of parenchymatous cells interrupted with few groups of pericyclic fibres and surrounding the central vascular cylinder which consists of phloem and xylem encircling wide pith.

The epidermis in transverse section (Fig. 5\&6) is formed of one row of sub rectangular cellulosic cells covered with slightly thick cuticle; while in surface view (Fig. 5C) the cells are polygonal, axially elongated with straight anticlinal walls and covered with smooth cuticle. They measure about (50-70-90) $\mu$ in length, (10-16-22) $\mu$ in width and (12-1518) $\mu$ in height. Anomocytic type of stomata is present but no hairs are observed.

The cortex (Figs. 5\&6) consists of two rows of thick-walled cellulosic chollenchymatous cells, followed by a parenchymatous region consisting of 4-6 layers of cellulosic cells with intercellular spaces, containing starch granules which are mostly simple and measuring (1.5-23) $\mu$ in diameter. Several scattered brownish laticiferous tubes are present measuring (20-3040) $\mu$ in diameter. The endodermis is indistinct.

The pericycle (Figs. 5\&6) separates the central stele from the cortex and it is formed of a continous ring of parenchymatous cells interrupted with groups of fibres with thick lignified walls and moderately wide lumina, measuring about (395-417-430) $\mu$ in length and (35- $\underline{-5}-65) \mu$ in width.

The vascular system (Fig. 5) is represented by a continuous opened collateral vascular bundles. The vascular bundle consists of phloem and xylem separated by cambium cells.

The phloem (Figs. 5\&6) is formed of soft thin walled elements. It is formed of sieve tubes, companion cells and phloem parenchyma. Several scattered brown laticiferous tubes are present measuring about (12-15-17) $\mu$ in diameter.

The cambium (Figs. 5\&6) is formed of 2-3 layers of subrectangular, tangentially elongated and radially arranged meristematic cells.
The xylem (Figs. 5\&6) consists of a lignified comparatively narrow zone of distinctly radiating elements of vessels, fibres, trachieds and wood parenchyma. The vessels are radially arranged, showing lignified spiral, reticulate and pitted thickening measuring (20-30-45) $\mu$ in diameter. The wood fibres have thick lignified walls with wide lumena, tapering apices. They measure (300-320-350) $\mu$ in length and (6- $\underline{8}-12) \mu$ in diameter. The wood parenchyma consists of subrectangular cells with thick slightly lignified walls, measuring (100-120-150) $\mu$ in length and (18-20-25) $\mu$ in width. The medullary rays are usually uni-or biseriate formed of thin cellulosic sub rectangular cells in the phloem region and pitted lignified in the xylem region.

The pith (Figs. 5\&6) is formed of wide central zone of rounded or oval parenchymatous cells with thin cellulosic walls; pith cells toward the center are larger with intercellular spaces. They contain simple starch granules, measuring (2- $\underline{3}-$ 4) $\mu$ in diameter.

\section{Powdered stem (Fig. 6)}

The powdered stem is yellowish-green in color; it has a faint odor and a burning taste. It is characterized microscopically by the following features:

1- Fragments of polygonal, subrectangular axially elongated epidermal cells with straight anticlinal walls, covered with thin smooth cuticle and showing few anomocytic stomata.

2- Fragments of pericyclic fibres with wide lumina and thick lignified walls.

3- Fragments of unbranched laticeferous tubes containing latex which stain brown with iodine. (T.S).

4- Fragments of parenchymatous cells containing starch granules from the cortex and pith.

5- Fragments of lignified xylem vessels with spiral, reticulate and pitted thickening.

6- Fragments of wood fibers with acute apices having narrow lumena and thick lignified walls, in addition to lignified trachieds and trachiedal vessels.

7- Fragments of lignified wood parenchyma with thick pitted walls, in addition to subrectangular lignified pitted medullary ray cells. 


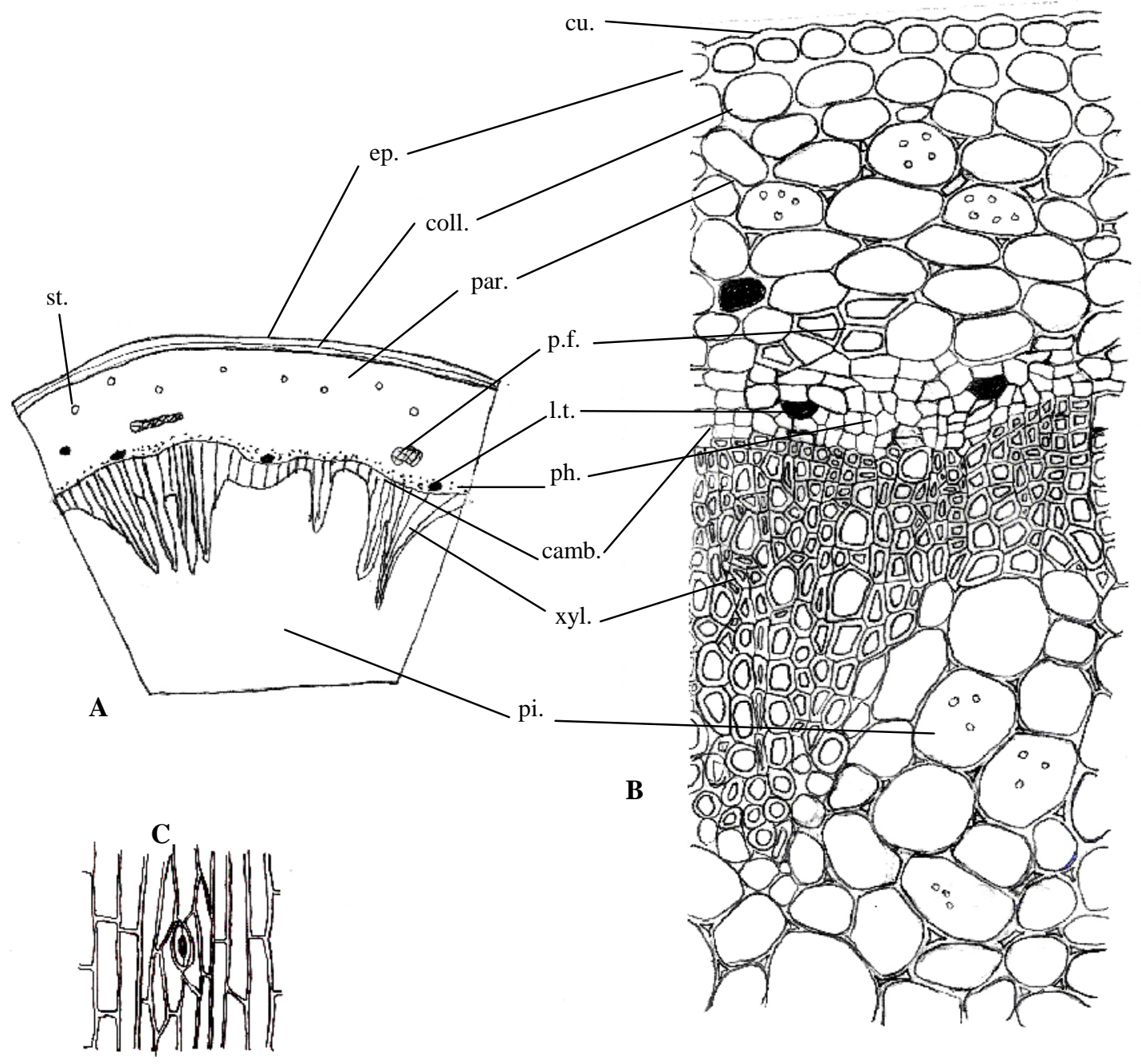

Fig. 5: The stem
A: Diagramatic T.S. of the stem
x 60
B: Detailed T.S. of the stem
$\mathrm{x} 150$
C: Surface preparation of the stem
x 300

camb.: cambium, coll.: collenchyma, ep.: epidermis, 1.t.: latex tube, par.: parenchyma, p.f.: pericyclic fibres, ph.: phloem, pi.: pith, xyl.: xylem. 


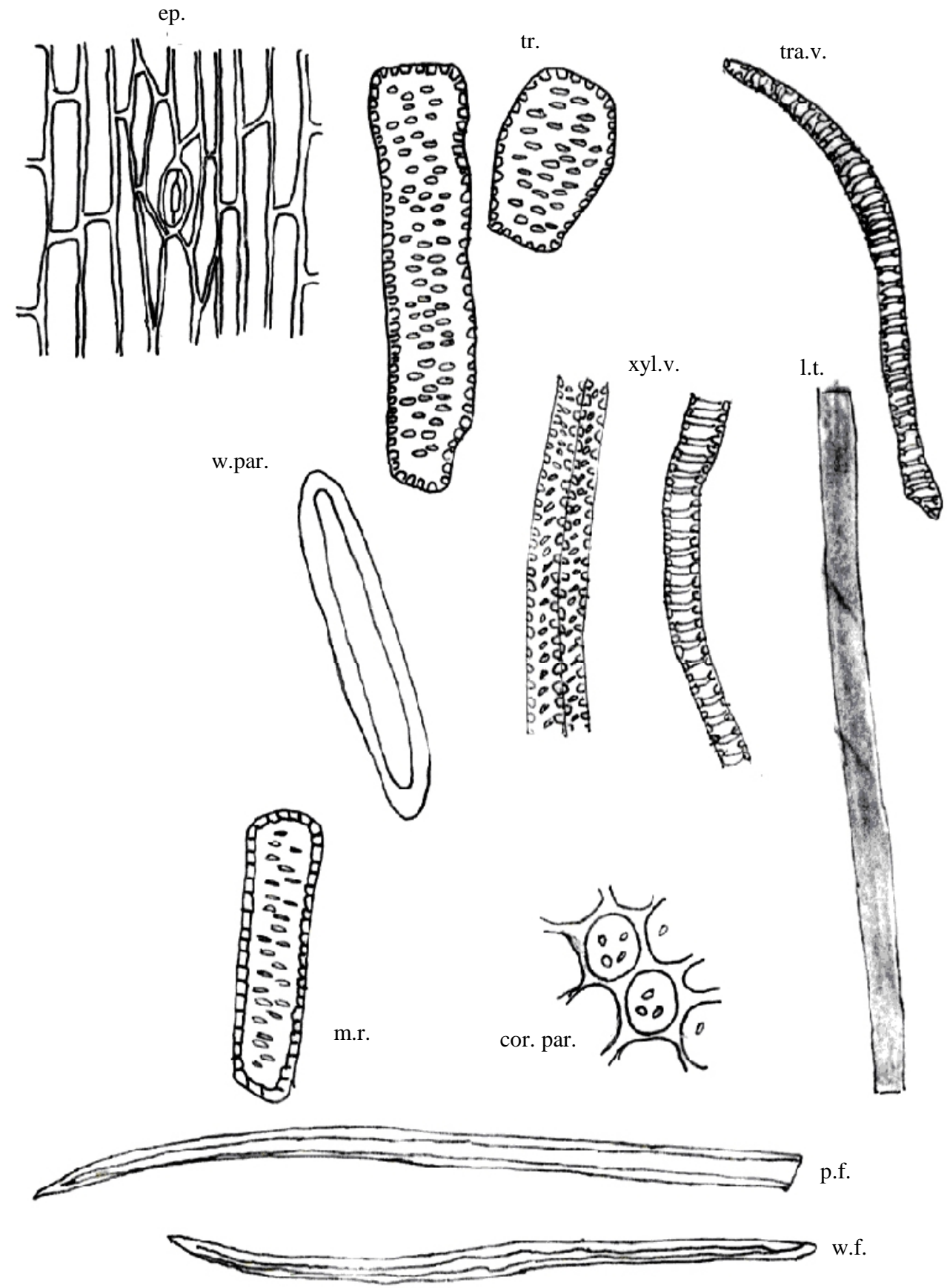

Fig. 6: Powder of the stem

$\mathrm{x} 150$

cor.par.: cortical parenchyma, ep.:, l.t.: latex tube, m.r.: medullary ray, p.f.: pericyclic fibre, tr.: trachieds, tr.v.: trachiedal vessels, w.f.: wood fibre, w.par.: wood parenchyma, xyl.v.: xylem vessels.

\section{THE LEAF}

\section{A) Macromorphology of the leaf (Figs. 1\&2)}

The leaves are simple, shortly petiolate to sessile, almost opposite, sometimes alternate. They are ovate to broadly ovate in shape, bright green in color and glabrous. It has an entire margin, obtuse to nearly rounded apex and symmetric base. The venation is pinnatereticulate and the texture is papery. It measures about (1.2-1.8-2.0) $\mathrm{cm}$ in length and about (0.5$0.7-0.9) \mathrm{cm}$ in width. It has faint odor and burning irritant taste. 


\section{B) Micromorphology of the leaf \\ I- The lamina (Fig. 7)}

A transverse section through the lamina in the midrib region (Fig. 7A\&D) is somewhat crescent shape in outline. It shows a dorsiventral structure with one layer of palisade underlying the upper epidermis; the palisade being interrupted in the midrib region by a few rows of collenchyma. The midrib region shows a central arc of vascular tissue consisting of a radiating xylem and lower soft phloem. Hairs or calcium oxalates are not observed.

The epidermis in transverse section (Fig. $7 A, B \& D)$ is formed of one row of sub rectangular cells covered with thick cuticle; while in surface view (Fig. 7C) they appear polygonal, nearly isodiametric with slightly wavy and peaded anticlinal walls. The cells are covered with thin smooth cuticle. The epidermal cells are measuring about (30-40-50) $\mu$ in length, (30-35-40) $\mu$ in width and (8- $\underline{10}-$ 12) $\mu$ in height. Hairs and stomata are not observed.

The lower epidermis in transverse section (Fig. 7A,B\&D) is formed of one row of subrectangular cells covered with thick cuticle; while in surface view (Fig. 7C) they are polygonal, mostly isodiametric with wavy peaded anticlinal walls covered with smooth cuticle, measuring about (40-ㅁ-65) $\mu$ in length, (30- $\underline{35-40)} \mu$ in width and (6- $\underline{-}-12) \mu$ in height. Stomata of anomocytic type are observed. The epidermal cells at the midrib region of both surfaces (Fig. 7C) are polygonal in surface view, with slightly wavy peaded anticlinal walls; they measure about (43-50-57) $\mu$ in length, (25- $\underline{30-40)} \mu$ in width and (6- $\underline{8}-10)$ $\mu$ in height.

The mesophyll is heterogenous showing an upper palisade consists of one row of nearly square cells, containing chloroplasts and measuring (15-20-25) $\mu$ in length, (10-15-20) $\mu$ in width (Fig. 7A\&B). They are interrupted in the midrib region by a narrow collenchymatous mass. They are nearly rounded cells with thick cellulosic walls. The spongy tissue consists of 4-5 rows of thin walled, rounded to slightly irregular parenchyma cells with intercellular spaces. The mesophyll is transversed by separate strands of small vascular bundles representing the veins. The spongy mesophyll shows somewhat irregular thin walled more or less rounded parenchymatous cells with intercellular spaces.

The cortical tissue consists of ordinary parenchyma surrounding the main vascular bundle of the midrib. There is a mass of collenchyma in the cortical region a butting the upper and lower epidermises.

The vascular system (Fig. 7A\&D) is represented by collateral vascular bundle of the midrib and the lateral bundles of the veins.

The pericycle is represented by a narrow zone of parenchymatous cells surrounding the phloem.

The phloem is represented by an arc of soft elements below the xylem. It is formed of thin walled cellulosic elements with few latex tubes which stained brown with iodine (T.S).

The xylem region consists of lignified spiral xylem vessels and thin walled wood parenchyma. The vessels measure about (7-1012) $\mu$ in diameter. The medullary rays are unito biseriate radially elongated, with thin cellulosic cells.

\section{II- The petiole}

A transverse section in the petiole (Fig. $7 \mathrm{E} \& \mathrm{~F})$ is a cresent shape. It shows an epidermis, followed by a ground tissue consisting of several layers of parenchymatous cells enclosing opened collateral vascular bundles. No hairs are observed. The epidermis consists of a single row of square to subrectangular cells. In surface view (Fig. 7G), they are polygonal, subrectangular to axially in shape having thin straight antilinal walls covered with thin smooth cuticle, measuring (40-50-70) $\mu$ in length, (7-10-15) $\mu$ in width and $(10-\underline{15}-20) \mu$ in height, stomata are rare and of anomoytic type. The cortex is consisting of parenchyma cells containing chloroplasts. The phloem consists of small thin walled soft elements and few scattered unbranched laticeferous tubes. The xylem is formed of lignified spiral xylem vessels and non lignified wood parenchyma. 

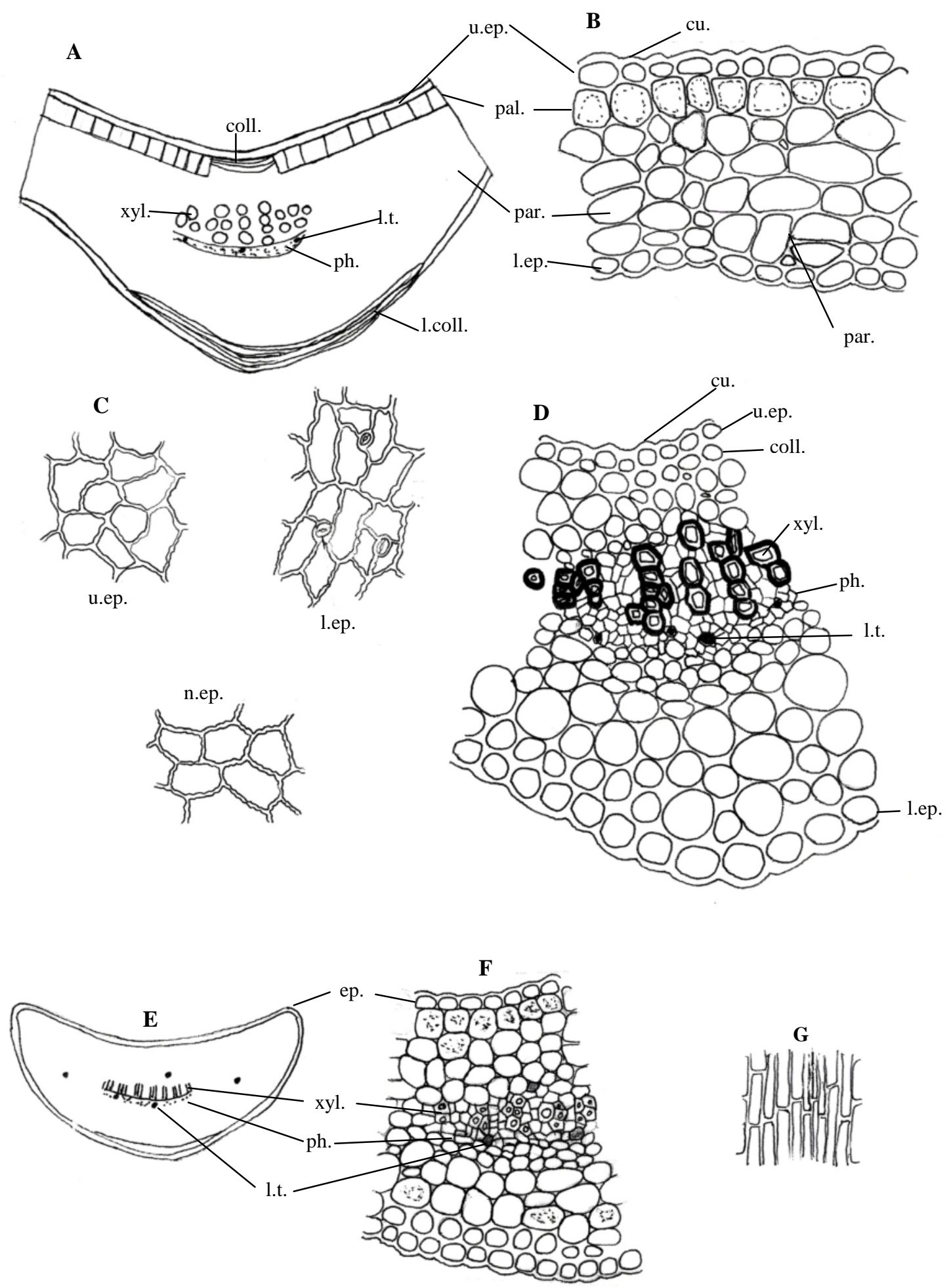

Fig.7: The leaf and the petiole.

A: Digrammatic T.S. of the leaf

$\mathrm{x} 150$

B: Detailed T.S. in the lamina of the leaf

x 300

C: The surface preparations of the leaf

$\mathrm{x} 300$

D) Detailed T.S. in the midrib region

x 300

E) Diagrammatic T.S. of the petiole

x 60

F) Detailed T.S. of the petiole

$\mathrm{x} 150$

G) Surface preparation of the petiole

x 300

1.t.: latex tube, 1.coll.: lower cholenchyma, l.ep.: lower epidermis, n.ep.: neural epidermal cells, pal.: palisade cells, par.: parenchyma, ph.: phloem, st.: stomata, u.coll.: upper collenchyma, u.ep:. upper epidermis, xyl.: xylem. 


\section{Powdered leaf (Fig. 8)}

The powdered leaf is yellowish-green in color. It has a faint odor and burning taste. It is characterized microscopically by the following fragments:

1- Fragments of the upper epidermal cells of the leaves which are polygonal, nearly isodiametric in shape with peaded anticlinal walls and covered with thin smooth cuticle. Fragments of neural epidermal cells of the leaf which are subrectangular in shape with peaded anticlinal walls and covered with thin smooth cuticle.

2- Fragments of the lower epidermis of the leaf, they are polygonal, mostly isodiametric with wavy peaded anticlinal walls and covered with smooth cuticle. Stomata of anomocytic type are observed.

3- Fragments of lignified spiral xylem vessels are observed.

4- Fragments of cylindrical to square palisade cells containing chloroplasts.

5- Fragments of non branched laticeferous tubes containing latex which stain brown with iodine (T.S).

Microscopical numerical values of the leaf were described in table 1.

Table 1: Microscopical numerical values of the leaf.

\begin{tabular}{|l|c|c|}
\hline \multicolumn{1}{|c|}{ Numerical value } & $\begin{array}{c}\text { Upper } \\
\text { epidermis }\end{array}$ & $\begin{array}{c}\text { Lower } \\
\text { epidermis }\end{array}$ \\
\hline Stomatal number & - & $56-210$ \\
\hline Stomatal Index & - & $7.6-23$ \\
\hline Palisade ratio & $0.75-\underline{1}-1.25$ & - \\
\hline Vien islet number & \multicolumn{2}{|c|}{$35-\underline{38-40}$} \\
\hline
\end{tabular}

\section{THE INFLORESCENCE}

\section{A) Macromorphology of the inflorescence}

(Figs. 1\&2)

The inflorescence is a terminal or axillary cyme consisting of clusters of flowers. Each consists of a cup like cluster of modified leaves enclosing a female flower and several male flowers, it is known as cyathium which is a type of false flower characteristic for the genus Euphorbia. The involucral bracts (4-5) are fused to form a cup shaped structure with a hairy margin, measuring about $(2-\underline{4}-6) \mathrm{mm}$ in length and (1-2-4) $\mathrm{mm}$ in diameter. The flower is hermaphrodite, consisting of five male flowers enclosed in the cup shaped involucre, each consists of stamen carrying bilobed anther and a female flower consisting of tricarpellary ovary carried on a long pedicel which pushes it up and out the cyathium to be pollinated.

\section{B) Micromorphology}

Isolated element of the inflorescence is characterized microscopically by the presence of the following: (Fig. 9)

1- Fragments of unicellular non glandular hairs covered with warty cuticle. They are covering the involucre and measuring about (80-100-120) $\mu$ in length and (8-10-15) $\mu$ in width,

2- Small prisms of calcium oxalate obtained from parenchyma cells of involucre measuring about (10-13-17) $\mu$ in length and (10-12-15) $\mu$ in width.

3- Fragments of non-branched laticeferous tubes containing latex measuring about (610-17) $\mu$ in width.

4- Fragments of nearly spherical pollen grains which are covered with smooth cuticle and measure about (16-19-25) $\mu$ in diameter.

5- Fragments of lignified spiral xylem vessels.

6- Fragments of fibrous layer of anther measuring about (33-40-50) $\mu$ in length and (15-22-30) $\mu$ in width.

7- Fragments of papilosed stigma.

8- Fragments of the epidermal cells of ovary surface which are polygonal, slightly elongated to isodiametric with straight anticlinal walls and covered with smooth cuticle. They measure about (40-50-65) $\mu$ in length and (20-30-40) $\mu$ in width.

\section{THE FRUIT}

\section{A) Macromorphology of the fruit (Fig. 2)}

It consists of condensed capsules, derived from trilocular superior ovary. Each fruit originates from pistillate flower. It is globular in shape measuring about (1- $\underline{3}-5) \mathrm{mm}$ in diameter and carried on a short stalk. It is yellowish green in color when mature. It carries remains of the stigma at its apex. It splits and opens explosively when ripe. There are three seeds per capsule. The seed is oblong in shape with greyish surface measuring about (1-1.5-2) $\mathrm{mm}$ in length and about (0.3-0.5-0.7) $\mathrm{mm}$ in width, carrying a fleshy outgrowth (caruncle) at the point of attachment to the centre of the fruit. The raphe extends all over the length of the seed (anatropous). 

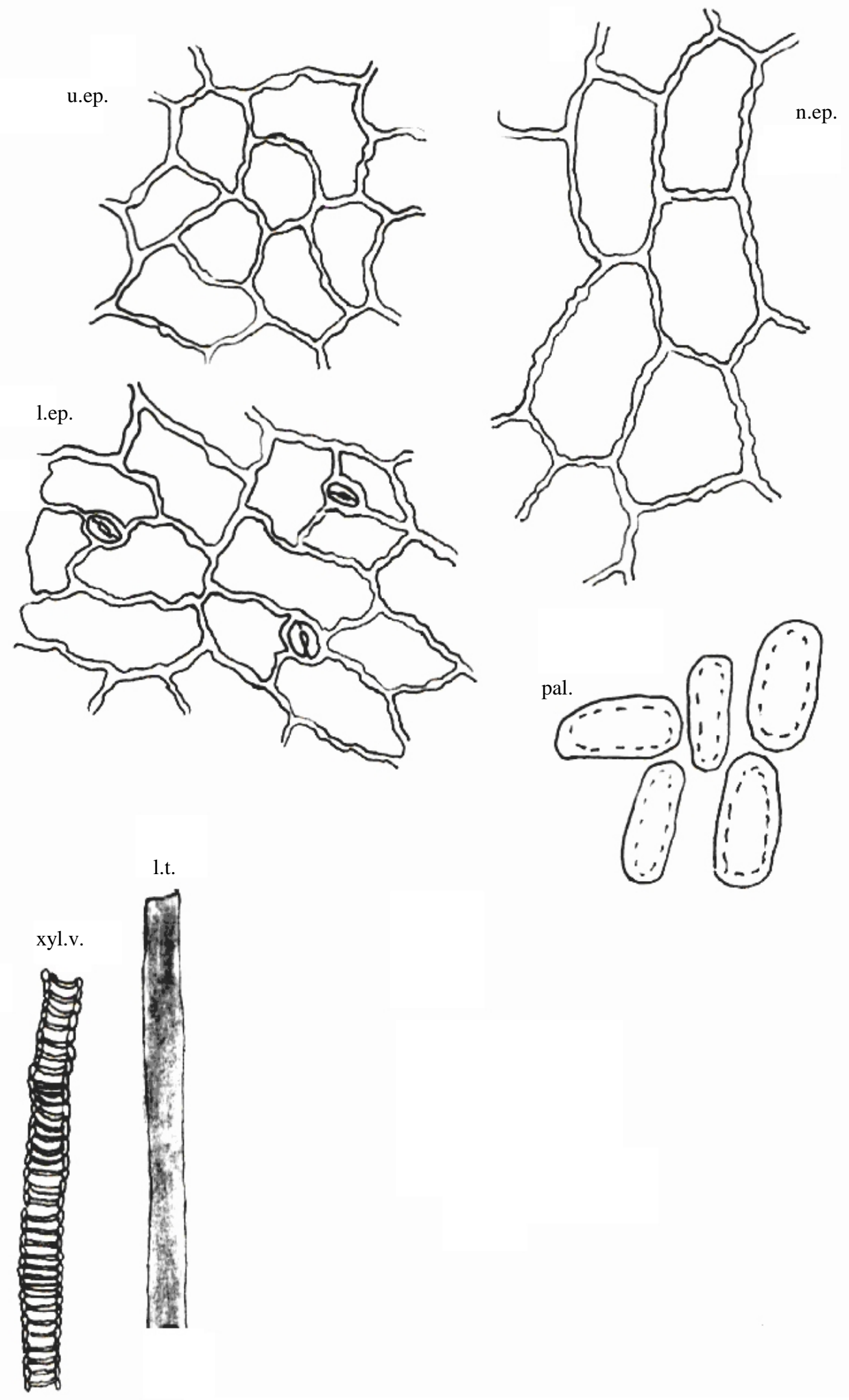

Fig. 8: Fragments of powdered leaf

1.ep.: lower epidermis, 1.t.: laticeferous tube, n.ep.: neural epidermis, pal.: palisade cells, u.ep.: upper epidermis, xyl.v.: xylem vessel. 

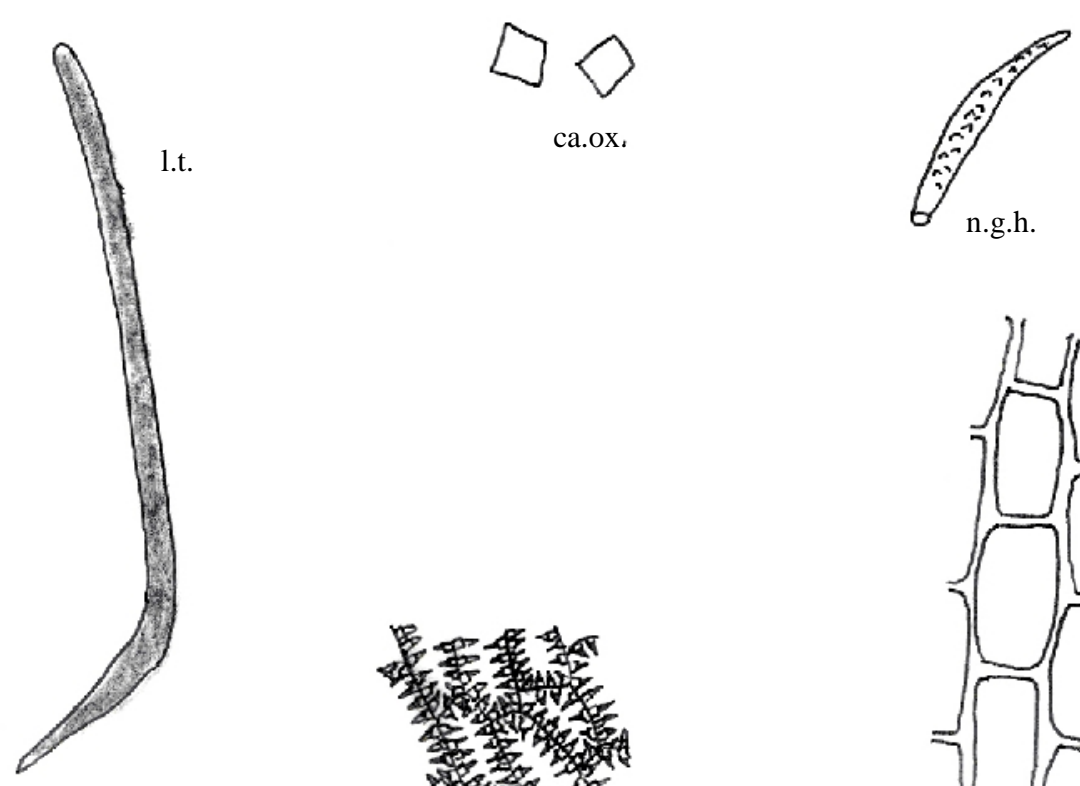

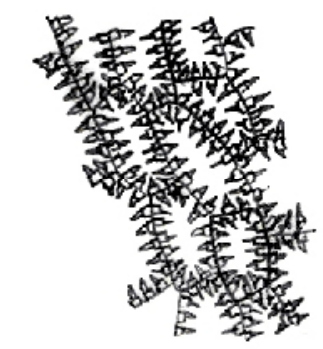

f.1.an.

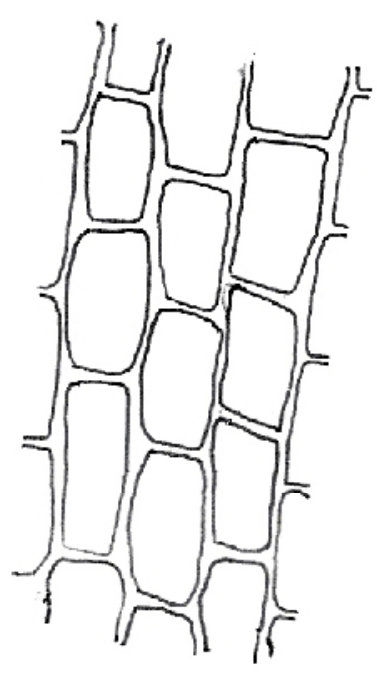

ep.ov.
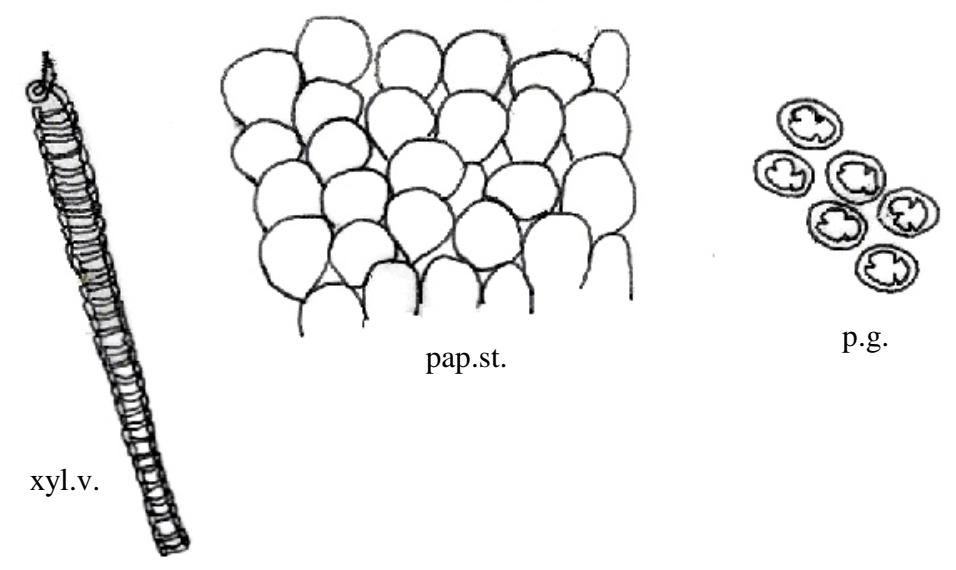

Fig. 9: Isolated elements of the inflorescence

x 300

ca.ox.: prisms of calcium oxalate, ep.ov.: epidermis of ovary, f.l.an.: fibrous layer of anther, l.t.: latex tube, n.gl.h.: non glandular hair, pap.st.: papilosed stigma, p.g.: pollen grain, xyl.v.: xylem vessels.

\section{B) Micromorphology of the fruit (Fig. 10)}

A transverse section through the capsule (Fig. 10) appears nearly triangular in outline. It consists of three locules each containing one albumenous seed. The structure consists of an outer epicarp consisting of one row of subrectangular cells, no hairs were observed.
The mesocarp is represented by a wide zone consisting of ordinary parenchymatous tissues centered by a wide sclerenchymatous structure; this structure is represented by fused transverse and tangential fibres. The endocarp is represented by one row of nearly sub rectangular cells. 
A

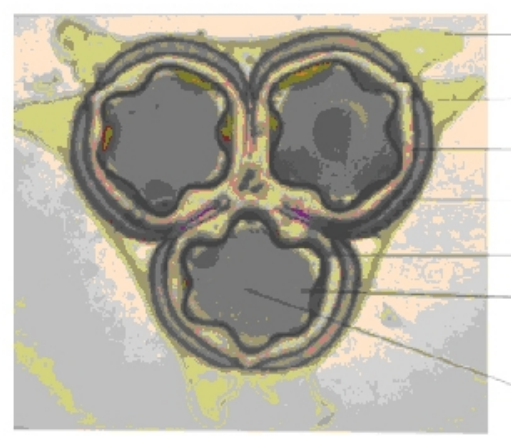

Fig. 10:

A- Photo of diagrammatic T.S. of the fruit B - Diagrammatic T.S. of the fruit
B

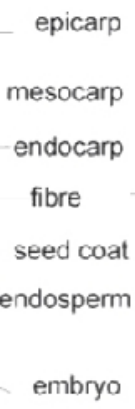

embryo
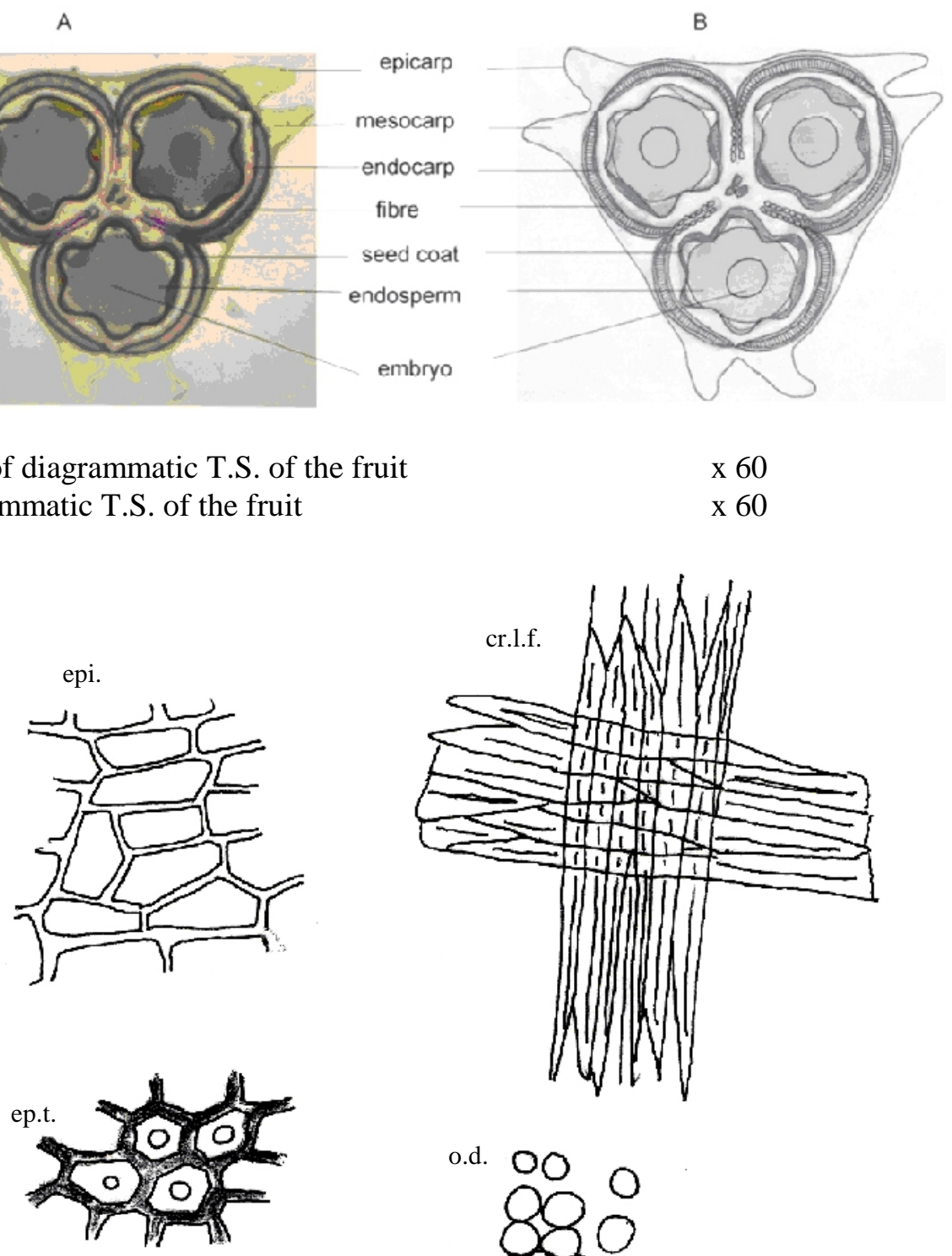

o.d.

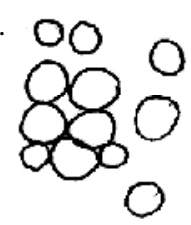

ca.ox.

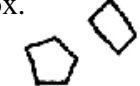

xyl.v.

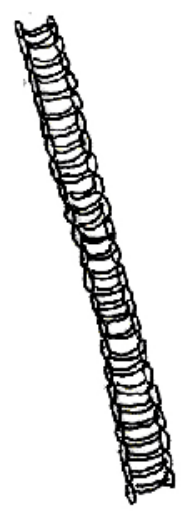

Fig. 11: Isolated elements of the fruit x 300

ca.ox.: prisms of calcium oxalate, cr.l.f.: cross layer of fibres, ep.t.: epidermis of testa, epi.: epicarp, end.: endosperm, o.d.: oil droplets, xyl.v.: xylem vessels. 


\section{Isolated elements of the fruit}

Microscopical examination of the isolated elements of the fruits (Fig. 11) showed the following fragments:

1- Fragments of epicarp cells which appear polygonal subrectangular in shape with straight anticlinal walls covered with smooth cuticle and free from stomata or hairs, measuring (40-50-60) $\mu$ in length and (16-20-30) $\mu$ in width.

2- Fragments of cross linked lignified, fusiform fibres from the mesocarp measuring about (150-200-250) $\mu$ in length and (16-18-30) $\mu$ in width.

3- Fragments of epidermal cells of the testa which are polygonal, nearly isodiametric with thick non lignified walls and contain brown pigments.

4- Small prisms of calcium oxalate measuring about (15-17-19) $\mu$ in length and (10-1215) $\mu$ in width.

5- Fragments of spiral and reticulated xylem vessels from the pedicel of the fruit.

6- Fragments of endosperm cells which are polygonal in shape with thin straight anticlinal walls, containing oil droplets and aleurone grains.

\section{Conlusion}

Both macro- and microscopical characters of Euphorbia peplus L. complies with those published in the literature dealing with the characters of plants belonging to the genus Euphorbia and those of the family ${ }^{22}$.

Leaf include ordinary laminate type with a dorsiventral mesophyl, upper and lower epidermal cells were covered with thick cuticle, stomata of anomocytic type were confined to the lower surface, vascular bundles were surrounded by parenchymatous cells, laticeferous tubes were found mostly in the phloem. Both sclerenchyma and intraxylary phloem were absent. Other characters were absent in the plant leaf and present in others of the family as glandular, nonglandular, stinging hairs, laticeferous cells, laticeferous sac, tannin sac and resinous content.

Stem epidermal cells with a persistent thick walled, the primary cortex was found to contain collenchyma, endodermis was not well defined, laticeferous tubes were found mostly in the phloem and primary cortex, pericycle with isolated strands of fibres, xylem was in the form of continous cylinder traversed by narrow medullary rays and sclerenchyma cells were absent. Other characters were absent in the plant stem and present in others of the family as cork cells, stone cells and fibres in the pith.

Root of Euphorbia peplus L. showed an irregular narrow brownish cork surrounding a narrow bark consisting of parenchymatous phelloderm. Numerous laticiferous tubes were found in the phloem and secondary cortex.The vascular bundle is composed of a narrow scanty phloem containing several scattered yellowish brown laticiferous tubes and wide xylem separated by few rows of cambial cells and traversed longitudinally by uni- and biseriate medullary ray cells. While of other members of Family Euphorbiaceae ${ }^{22}$ were characterized by thick homogenous cork, broad secondary cortex, phloem was scanty, the xylem in the form of narrow radiate groups.

\section{REFERENCES}

1- L. E. Core, "Plant Taxonomy", Englewood Cliffs, 1962, pp. 345-47.

2- G. H. M. Lawrence, "Taxonomy of Vascular Plants", New York, the Macmillan Co., 1968, pp. 564-67.

3- V. Tackholm,"Students' Flora of Egypt", Cairo University, Cooperative Printing Co., 1974, pp. 319-32.

4- K. R. Kirticar, B. D. Basu and I. C. S. An, "Indian Medicinal Plants", $2^{\text {nd }}$ Ed., M/S Periodical Experts, Delhi, 1975, pp. 219096.

5- C. L. Porter, "Taxonomy of Flowering Plants", Eurasia Publishing House (pvt.) Ltd., 1955, pp. 324-325.

6- G. L. Chopra, "Angiosperms", S. Nagin. Co., 1973, pp. 389-95.

7- L. Benson, "Plant Classification", Oxford \& Ibh publishing Co., 1957, p. 159.

8- L. Boulos, "Medicinal Plants of North Africa", Firewood Crops, 1980, p. 83.

9- L. H. Baily, "The Standard Cyclopedia of Horticulture", New York, the MacMillan Co., $11^{\text {th }}$ Edithion, 1963, pp. 1167-75.

10- I. Mucsi, J. Molnar, J. Hohmann and D. Redei, "Cytotoxicities and anti-herpes 
simplex virus activities of diterpenes isolated from Euphorbia species", Planta Med., 67 (4), 672-674 (2001).

11- J. M. Watt and M. G. Breyer-Brandwijk, "Medicinal and Poisonous Plants of Southern and Eastern Africa", E. \& S. Livingostone Ltd. Edinburgh and London, 1962, pp. 395-438.

12- J. Hohmann, G. Gunther, A. Vasas, A. Kalman and G. Argay, "Isolation and structure revision of pepulane diterpenoids from Euphorbia peplus", J. Nat. Prod., 62 (1), 107-109 (1999).

13- J. Jakopovic, T. Morgenstern, M. Bittner and M. Silva,"Diterpenes from Euphorbia peplus", Phytochemistry, 47 (8), 16011609 (1998).

14- J. Giner, D. J. Berkowitz and T. Anderson, "Non polar components of the latex of Euphorbia peplus", J. Nat. Prod., 63 (2), 267-269 (2000).

15- M. J. U. Ferreira, A. M. Lobo and H. Wyler, "Triterpenoids and Steroids from Euphorbia peplus", Fitoterapia, LXIV (1), 85-87 (1993).

16- S. Zhi-Qin, M. Shu-Zhen, D. Ying-Tong and H. Xiao-Jiang, "A New jatrophane diterpenoid from Euphorbia peplus", Chinese Journal of Natural Medicines, 8 (2), 81-83 (2010).
17- J. Homanna, A. Vasas, G. Gunther, G. Dombi, G. Blazso, G. Falky, I. Mathe and G. Jerjovich, "Jatrophane diterpenoids from Euphorbia peplus", Phytochemistry, 51 (4), 673-677 (1999).

18- J. Jakopovic, T. Morgenstern, M. Bittner and M. Silva,"Diterpenes from Euphorbia peplus", ibid., 47 (8), 1601-1609(1998).

19- K. Dumkow and R. Pohl, "Isolation of flavonoids from Euphorbia peplus", Planta Med., 24 (2), 145 (1973).

20- A. M. Rizk, F. M. Hammouda, H. M. ElMissiry, M. H. Radwan and J. F. Evans, "Investigation of Euphorbia peplus", Fitoterapia, 51 (4), 223-227 (1980).

21- A. A. Ali, H. M. Sayed, S. R. M. Ibrahim and A. M. Zaher, "Chemical constitutents, antimicrobial, analgesic, antipyretic and anti-inflammatory activities of Euphorbia peplus L.", Phytopharmacology, 4 (1), 6980 (2013).

22- C. R. Metcalf and L. Chalk, "Anatomy of Dicotyledons", Vol. 2, The Clarendon Press, Oxoford, 1950, pp. 1209-1235. 


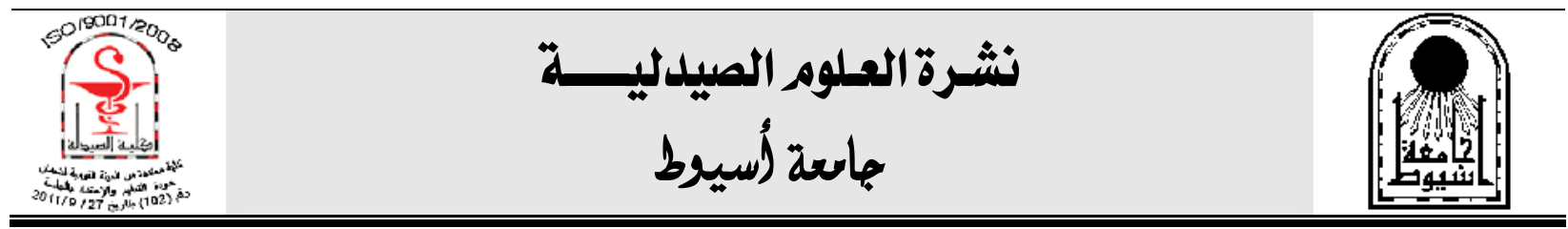

دراسة الصفات العياتية والمجهرية للجذر والساق والآوراق والازهار والثمرة لتبات الآقوربيا بيبلس المئ. الأي ينمو في مصر والأور

أحمد عبد الرحمن علي - هناء محمد سيد - صابرين رجب محمد - أحمد محمد زاهر

قسم العقاقير ، كلية الصيدلة ، جامعة أسيوط

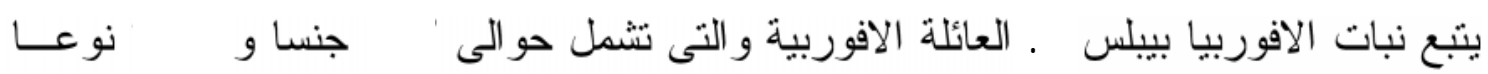

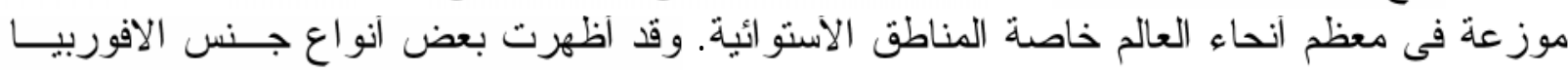

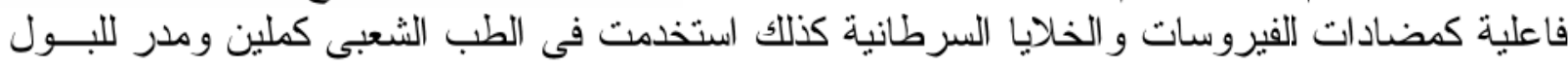

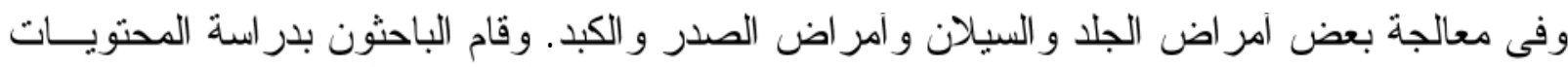

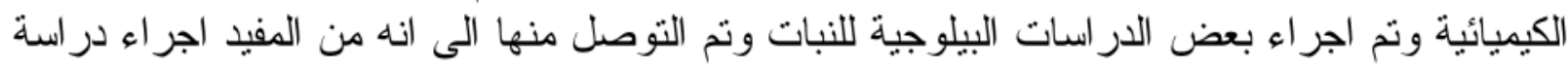

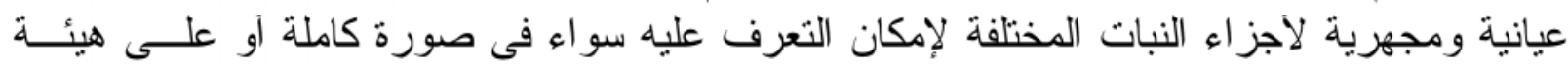
مسحوق. 